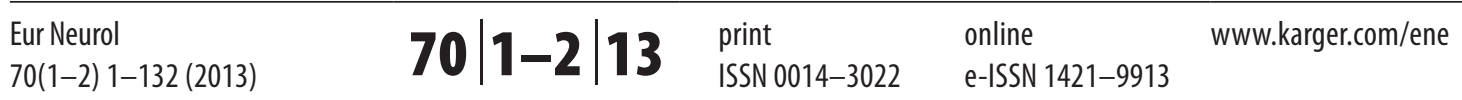
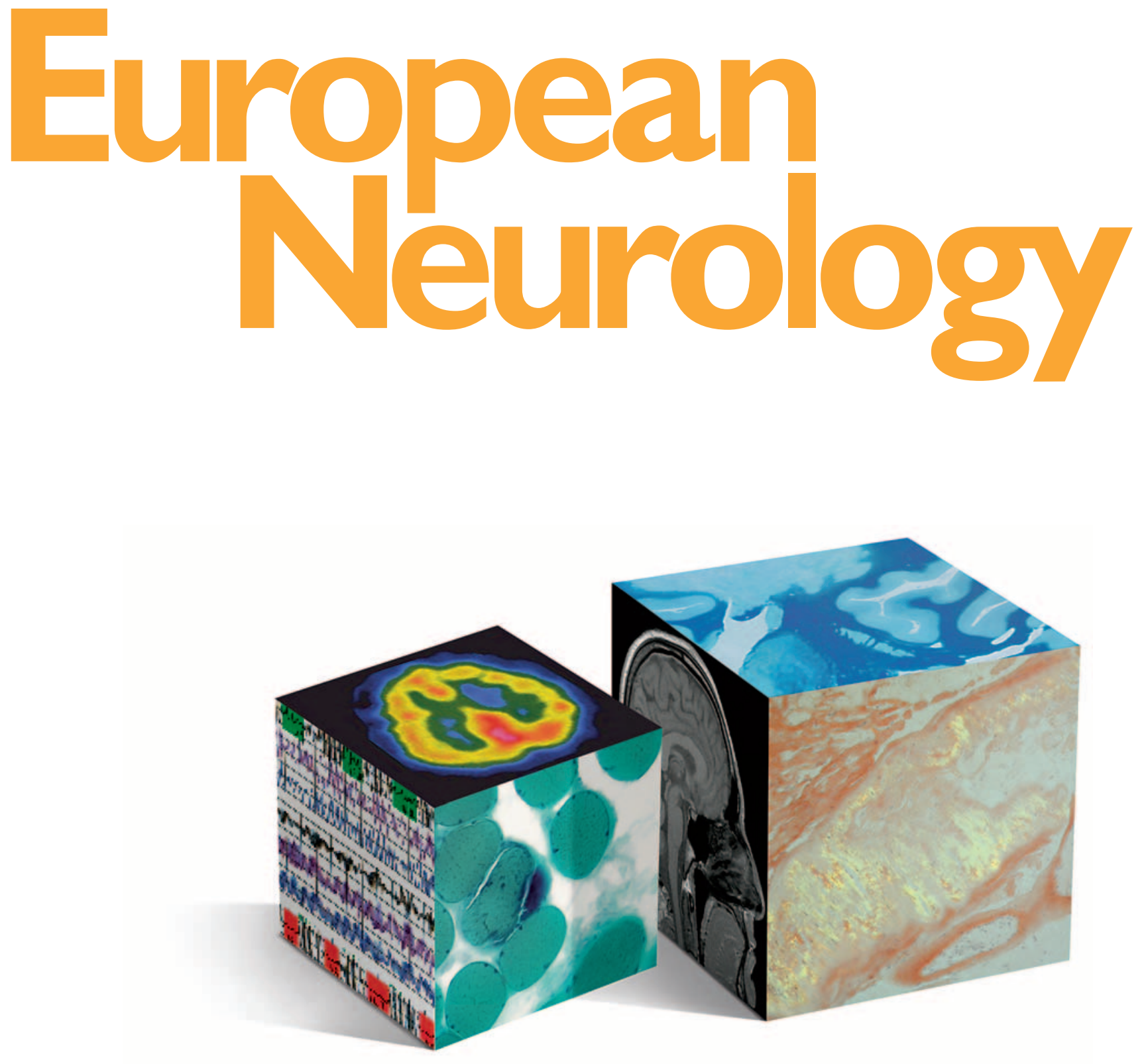

S. Karger

Medical and Scientific Publishers $\mathrm{KA} \mathrm{RGER}$ Basel · Freiburg · Paris .

London - New York .

New Delhi · Bangkok · Beijing ·

Tokyo $\cdot$ Kuala Lumpur .

Singapore $\cdot$ Sydney 
SickKids Handbook of Pediatric Thrombosis and Hemostasis

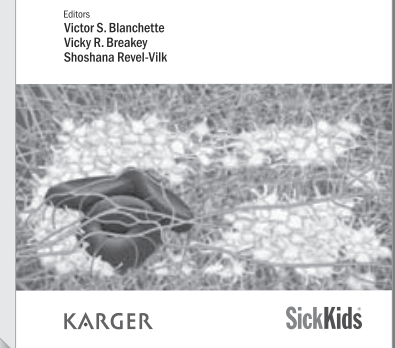

An expertly written, practical handbook for the clinical assessment and management of children with inherited and acquired bleeding and clotting disorders

\section{SickKids Handbook of Pediatric Thrombosis and Hemostasis}

\author{
Editors
}

Victor S. Blanchette

Vicky R. Breakey

Shoshana Revel-Vilk
SickKids Handbook of Pediatric Thrombosis and Hemostasis

Editors: V. Blanchette (Toronto, Ont.):

V.S. Breakey (Hamilton, Ont.);

S.R. Revel-Vilk (Jerusalem)

XVIII + 254 p., 23 fig., 9 in color, 9 algorithms, 59 tab., 2013

CHF 160.- / EUR 133.- / USD 188.00 (soft cover) CHF 192.- / EUR 160.- / USD 226.00 (online) Online version for institutional purchase Prices subject to change

EUR price for Germany, USD price for USA only ISBN 978-3-318-02197-4 (soft cover) e-ISBN 978-3-318-02198-

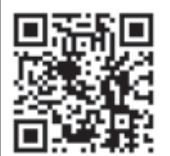

Dear Librarian

have reviewed this publication and would like to recommend it for our library. Recommended by:

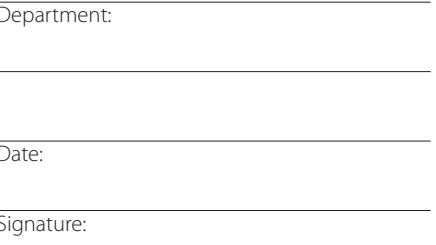

This handbook takes the reader through the entire field of pediatric thrombosis and hemostasis.

An introductory section concisely explains the complex pathophysiology of hemostasis and thrombosis. The chapters that follow include practical, evidencebased information on the diagnosis and management of inherited and acquired bleeding disorders and thrombotic events of the venous, arterial, cardiac and central nervous systems that affect children. Special features include practical clinical algorithms and appendices that cite normal laboratory reference ranges, as well as recommended dosages of blood products and major hemostatic agents. A standalone chapter is dedicated to developmental hemostasis and bleeding in the neonate. A chapter on antithrombotic therapy in children gives succinct information on the old and new anticoagulants, antiplatelet drugs and thrombolytic agents.

Written and reviewed by international experts in the field, this handbook is intended for health care professionals involved in the assessment and care of children with inherited and acquired bleeding and clotting disorders, including general and specialist pediatricians (in particular intensivists, neonatologists, cardiologists/cardiac surgeons, rheumatologists and nephrologists), hematologists/oncologists (pediatric and adult), as well as medical trainees, nurses, nurse practitioners and pharmacists.

\section{Contents}

- Contributors

- Preface

- Pediatric Thrombosis and Hemostasis: A Historical Perspective: Breakey, V.R.; Blanchette, V.S.

- Primary and Secondary Hemostasis, Regulators of Coagulation, and Fibrinolysis: Understanding the Basics: Revel-Vilk, S.; Rand, M.L.; Israels, S.J.

-An Approach to the Bleeding Child: Revel-Vilk, S.; Rand, M.L.; Israels, S.J.

- Bleeding in the Neonate: Avila, L.; Barnard, D. - Platelet Disorders in Children: van Eimeren, $\mathbf{V}$; Kahr, W.H.A.

- Managing Hemophilia in Children and Adolescents: Robertson, J.D.; Curtin, J.A.; Blanchette, V.S.

-von Willebrand Disease in Children: Breakey, V.R.; Carcao, M.

- Rare Congenital Factor Deficiencies in Childhood Xavier, F.; Blanchette, V.S.

- Acquired Bleeding Disorders in Children: Kumar, R.; Steele, M.

- A Diagnostic Approach to a Child with

Thrombosis: Rizzi, M.; Barnes, C.

-Venous Thrombosis: Price, V.E.; Brandão, L.R.; Williams, S.

- Arterial Thrombosis: Revel-Vilk, S.; Albisetti, M.; Massicotte, M.P.

-Thromboembolic Events at Specific Organ Sites: Labarque, V.; Chan, A.K.C.; Williams, S.

-Pediatric Stroke: Andrade, A.; Ichord, R.; Dlamini, N.; Williams, S.; deVeber, G.

- Bleeding and Clotting in Children with Cardiac

Disease: Diab, Y.; McCrindle, B.W.; Brandão, L.R.

- Antithrombotic Therapy in Children: Biss, T.;

Monagle, $\mathrm{P}$.

- Appendix I: Reference Ranges for Common Tests of Bleeding and Clotting: Breakey, V.R.

-Appendix II: Common Products Used to Manage Bleeding and Clotting: Simpson, E.; Liebman, M.

- Abbreviations

- Subject Index

\section{The easiest way to order: www.karger.com/sickkids}

Karger - Medical and Scientific Publishers

$\mathrm{CH}-4009$ Basel, Switzerland

orders@karger.com, f: +41 613061234

www.karger.com 


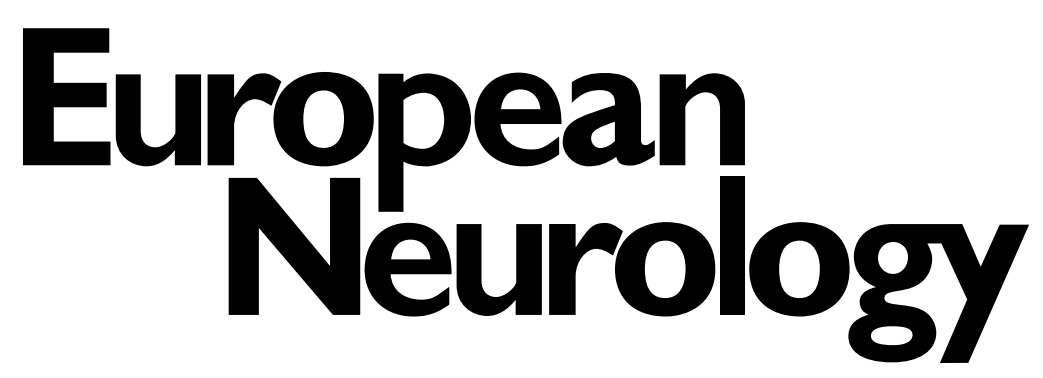

Founded 1897 as 'Monatsschrift für Psychiatrie und Neurologie', continued 1957-1967 as 'Psychiatria et Neurologia'

Founders: C. Wernicke and Th. Ziehen.

Successors: K. Bonhoeffer (1912-1938), J. Klaesi (1939-1967), E. Grünthal (1953-1967),

H.E. Kaeser (1968-1993)

\section{Editor-in-Chief}

J. Bogousslavsky, Montreux

\section{Section Editor 'Neuro-Update'}

C. Bassetti, Berne

\section{Editorial Board}

H. Adeli, Columbus, Ohio

A. Amato, Boston, Mass.

M. Arnold, Berne

K. Bhatia, London

F. Boller, Rockville, Md.

P. Boon, Ghent

E. Broussolle, Lyon

C. Buckley, Oxford

J.-M. Burgunder, Berne

P. Calabrese, Basel

A. Carota, Genolier

R.J. Castellani, Baltimore, Md.

A.K. Chatterjee, Philadelphia, Pa.

G. Deuschl, Kiel

V. Di Piero, Rome

N.M.J. Edelstyn, Keele

T. Ettlin, Rheinfelden

M. Filippi, Milan

S. Gauthier, Montreal, Que.

C. Gerloff, Hamburg

P. Giannakopoulos, Geneva

F. Graus, Barcelona

B. Greenberg, Dallas, Tx.

H.-P. Hartung, Düsseldorf

R.A. Hauser, Tampa, Fla.

J.J. Hauw, Paris

T.S. Jensen, Aarhus

R.N. Kalaria, Newcastle upon Tyne

T. Karapanayiotides, Thessaloniki
U. Koedel, Munich

H. Lassmann, Vienna

N. Leigh, London

K.O. Lövblad, Geneva

A. May, Hamburg

M.N. Meriggioli, Chicago, Ill.

J. Mocayo Gaete, Quito

X. Montalban, Barcelona

E. Mori, Sendai

T. Moulin, Besançon

H. Naritomi, Osaka

E. Nobile-Orazio, Milan

M. Paciaroni, Perugia

A. Raabe, Berne

A.O. Rossetti, Lausanne

D. Russell, Oslo

S. Sacco, L'Aquila

C. Saper, Boston, Mass.

K. Schaller, Geneva

M. Schüpbach, Berne

N. Scolding, Bristol

M. Seeck, Geneva

V. Silani, Milan

L. Tatu, Besançon

A. Tsiskaridze, Tbilisi

J.M. Vallat, Limoges

P. Van den Bergh, Brussels

B.V. Vaughn, Chapel Hill, N.C.

O.W. Walusinski, Brou
Printed in Switzerland on acid-free and non-aging paper (ISO 9706) by

Reinhardt Druck, Basel
Appears monthly: 2 volumes per year (12 issues) 


\section{European Neurology}

\section{Aims and Scope}

'European Neurology' publishes original papers, reviews and letters to the editor. Papers presented in this journal cover clinical aspects of diseases of the nervous system and muscles, as well as their neuropathological, biochemical, and electrophysiological basis. New diagnostic probes, pharmacological and surgical treatments are evaluated from clinical evidence and basic investigative studies. The journal also features original works and reviews on the history of neurology. Submission

Only original papers written in English are considered and should be submitted online:

www.karger.com/ene

Should you experience any problems with your submission, please contact:

\author{
ene@karger.com \\ S. Karger AG \\ Editorial Office 'European Neurology' \\ $\mathrm{CH}-4009$ Basel (Switzerland) \\ Tel. +41613061573 \\ Fax +41613061434
}

Names, postal and e-mail adresses of 6 experts in the appropriate area of research should accompany each manuscript Referees suggested should not be from the same institution or be research collaborators of the author(s) and preferably not from the same country of the authors.

\section{Conditions}

All manuscripts are subject to editorial review. Manuscripts are received with the explicit understanding that they are not under simultaneous consideration by any other publication. Submission of an article for publication implies transfer of the copyright from the author to the publisher upon acceptance. Accepted papers become the permanent property of 'European Neurology' and may not be reproduced by any means, in whole or in part, without the written consent of the publisher. It is the author's responsibility to obtain permission to reproduce illustrations, tables, etc. from other publications.

\section{Conflicts of Interest}

Authors are required to disclose any sponsorship or funding arrangements relating to their research and all authors should disclose any possible conflicts of interest. Conflict of interest statements will be published at the end of the article.

Published research must comply with the guidelines for human studies and animal welfare regulations. Authors should state that subjects have given their informed consent and that the study protocol has been approved by the institute's committee on human research. Further, they should also state that animal experiments conform to institutional standards.

\section{Categories of Manuscripts}

Original Papers are full-length research papers which will be considered for the journal. Articles cover topics relevant to clinical studies. Basic and experimental work appear only if directly related to clinical issues (max. 3,000 words).

Reviews in which a specific field is reviewed through an exhaustive literature survey. An Abstract is required and should be divided into Background, Summary and Key Messages. Review Articles should consist of a maximum of 4,000 words.

Neuroimages are previously unpublished photomicrographs, patient photographs, neuroradiologic images, or other pictorial material (max. 100 words, two figures with legend, and up to two references).

\section{Plagiarism Policy}

Whether intentional or not, plagiarism is a serious violation. We define plagiarism as a case in which a paper reproduces another work with at least $25 \%$ similarity and without citation.

If evidence of plagiarism is found before/after acceptance or after publication of the paper, the author will be offered a chance for rebuttal. If the arguments are not found to be satisfactory, the manuscript will be retracted and the author sanctioned from publishing papers for a period to be determined by the responsible Editor(s)

\section{Arrangement}

Title page: The first page of each paper should indicate the title, the authors' names, the institute where the work was conducted, and a short title for use as running head.

Full address: The exact postal address of the corresponding author complete with postal code must be given at the bottom of the title page. Please also supply phone and fax numbers, as well as e-mail address.

Key words: Please supply 3-10 key words in English that reflect the content of the paper.

Abstracts of Reviews: Should be divided into the following subsections: Background, Summary and Key Messages. The Background should provide a brief clinical context for the review and is followed by the Summary, which should include a concise description of the main topics covered in the text. The Key Messages encapsulate the main conclusions of the review.

Abstract: Each paper needs an abstract of up to 10 lines (except for letters to the editor).

Footnotes: Avoid footnotes.

Tables and illustrations: Tables and illustrations (both num bered in Arabic numerals) should be prepared on separate pages. Tables require a heading and figures a legend, also prepared on a separate page. For the reproduction of illustrations, only good drawings and original photographs can be accepted; negatives or photocopies cannot be used. Due to technical reasons, figures with a screen background should not be submitted. When possible, group several illustrations in one block for reproduction (max. size $180 \times 223 \mathrm{~mm}$ ) or provide crop marks. Electronically submitted b/w half-tone and color illustrations must have a final resolution of $300 \mathrm{dpi}$ after scaling, line drawings one of $800-1,200 \mathrm{dpi}$.

\section{Color illustrations}

Online edition: Color illustrations are reproduced free of charge. In the print version, the illustrations are reproduced in black and white. Please avoid referring to the colors in the text and figure legends.

Print edition: Up to 6 color illustrations per page can be integrated within the text at CHF 800.- per page.

References: In the text identify references by Arabic numerals [in square brackets]. Material submitted for publication but not yet accepted should be noted as 'unpublished data' and not be included in the reference list. The list of reference should include only those publications which are cited in the text. Do not alphabetize; number references in the order in which they are first mentioned in the text. The surnames of the authors followed by initials should be given. There should be no punctuation other than a comma to separate the authors. Preferably, please cite all authors. Abbreviate journal names according to the Index Medicus system. Also see International Committee of Medical Journal Editors: Uniform requirements for manuscripts submitted to biomedical journals (www.icmje.org).

Examples

(a) Papers published in periodicals: Chatel J-M, Bernard $\mathrm{H}$, Orson FM: Isolation and characterization of two complete Ara h 2 isoforms cDNA. Int Arch Allergy Immunol 2003;131:14-18.

(b) Papers published only with DOI numbers:

Theoharides TC, Boucher W, Spear K: Serum interleukin-6 reflects disease severity and osteoporosis in mastocytosis patients. Int Arch Allergy Immunol DOI: 10.1159/000063858. (c) Monographs: Matthews DE, Farewell VT: Using and Understanding Medical Statistics, ed 3, revised. Basel, Karger, 1996

(d) Edited books: DuBois RN: Cyclooxygenase-2 and colorectal cancer; in Dannenberg AJ, Dubois RN (eds): COX-2. Prog Exp Tum Res. Basel, Karger, 2003, vol 37, pp 124-137.
Reference Management Software: Use of EndNote is recommended for easy management and formatting of citations and reference lists.

\section{Digital Object Identifier (DOI)}

S. Karger Publishers supports DOIs as unique identifiers for articles. A DOI number will be printed on the title page of each article. DOIs can be useful in the future for identifying and citing articles published online without volume or issue information. More information can be found at www. doi.org.

\section{Supplementary Material}

Supplementary material is restricted to additional data that are not necessary for the scientific integrity and conclusion of the paper. Please note that all supplementary files will undergo editorial review and should be submitted together with the original manuscript. The Editors reserve the right to limit the scope and length of the supplementary material. Supplementary material must meet production quality standards for Web publication without the need for any modification or editing. In general, supplementary files should not exceed $10 \mathrm{MB}$ in size. All figures and tables should have titles and legends and all files should be supplied separately and named clearly. Acceptable files and formats are: Word or PDF files, Excel spreadsheets (only if the data cannot be converted properly to a PDF file), and video files (.mov, .avi mpeg)

\section{Author's Choice ${ }^{\mathrm{TM}}$}

Karger's Author's Choice ${ }^{\mathrm{TM}}$ service broadens the reach of your article and gives all users worldwide free and full access for reading, downloading and printing at www.karger.com. The option is available for a one-time fee of CHF 3000.which is a permissible cost in grant allocation. More information can be found at www.karger.com/authors_choice.

\section{NIH-Funded Research}

The U.S. National Institutes of Health (NIH) mandates un der the NIH Public Access Policy that final, peer-reviewed manuscripts appear in its digital database within 12 month of the official publication date. As a service to authors, Karger submits the final version of your article on your behal to PubMed Central. For those selecting our premium $\mathrm{Au}-$ thor's Choice ${ }^{\mathrm{TM}}$ service, we will send your article immediately upon publishing, accelerating the accessibility of your work without the usual embargo. More details on NIH's Public Access Policy is available at http://publicaccess.nih gov/policy.htm

\section{Self-Archiving}

Karger permits authors to archive their pre-prints (i.e. prerefereeing) or post-prints (i.e. final draft post-refereeing) on their personal or institution's servers, provided the following conditions are met: Articles may not be used for commercial purposes, must be linked to the publisher's version, and mus acknowledge the publisher's copyright. Authors selecting Karger's Author's Choice ${ }^{\mathrm{TM}}$ feature, however, are also permitted to archive the final, published version of their article, which includes copyediting and design improvements as well as citation links.

\section{Page Charges}

There are no page charges for papers of 3 or fewer printed pages (including tables, illustrations and references). Each additional complete or partial page is charged to the author at CHF 325.-. The allotted size of a paper is equal to approx. 8 manuscript pages (including tables, illustrations and references)

\section{Proofs}

Unless indicated otherwise, proofs are sent to the corresponding author and should be returned with the least possible delay. Alterations other than the correction of printer's errors are charged to the author.

\section{Reprints}

Order forms and a price list are sent with the proofs. Order submitted after the issue is printed are subject to considerably higher prices.

\section{KARGER}

E-Mail karger@karger.com www.karger.com
(C) 2013 S. Karger AG, Basel 


\section{European Neurology}

ISSN Print Edition: 0014-3022 ISSN Online Edition: 1421-9913

Journal Homepage: www.karger.com/ene

Publication Data: 'European Neurology' is published 12 times a year. Volumes 69 and 70, each with 6 issues, appear in 2013

Copyright: (c) 2013 S. Karger AG, Basel (Switzerland). All rights reserved. No part of this publication may be translated into other languages, reproduced or utilized in any form or by any means, electronic or mechanical including photocopying, recording, microcopying, or by any information storage and retrieval system, without permission in writing from the publisher or, in the case of photocopying, direct payment of a specified fee to the Copyright Clearance Center.

Disclaimer: The statements, opinions and data contained in this publication are solely those of the individual authors and contributors and not of the publisher and the editor(s). The appearance of advertisements in the journal is not a warranty, endorsement, or approval of the products or services advertised or of their effectiveness, quality or safety. The publisher and the editor(s) disclaim responsibility for any injury to persons or property resulting from any ideas, methods, instructions or products referred to in the content or advertisements.
Subscription Rates: Subscriptions run for a full calendar year. Prices are given per year. Personal subscription:

Print or Online

CHF 744.-

EUR 600.-

USD 737.00

Print+Online combined

USD 833.00

postage and handling (added to print and print+online)

CHF 86.40 Europe, CHF 124.80 Overseas

EUR 67.20

USD 115.20

Institutional subscription:

Print or Online

Print+Online combined

CHF 3722.

EUR 3002.-

CHF 4094.-

postage and handling (added to print and print+online)

CHF 108.- Europe, CHF 156.- Overseas

EUR 84.-

USD 144.00

Airmail surcharge: CHF 105.- / USD 99.00

Discount subscription prices:

European Neurological Society;

Belgian Society of Neurology.
Back Volumes and Single Issues: Information on availability and prices of single print issues and print or electronic back volumes can be obtained from Customer Service atservice@karger.com.

Bibliographic Indices: This journal is regularly listed in bibliographic services, including Current Contents ${ }^{\circledR}$ and PubMed/MEDLINE.

Photocopying: This journal has been registered with the Copyright Clearance Center (CCC), as indicated by the code appearing on the first page of each article. For readers in the US, this code signals consent for copying of articles for personal or internal use, or for the personal or internal use of specific clients, provided that the stated fee is paid per copy directly to

Copyright Clearance Center Inc.

222 Rosewood Drive

Danvers, MA 01923 (USA)

A copy of the first page of the article must accompany payment. Consent does not extend to copying for general distribution, for promotion, for creating new works, or for resale. In these cases, specific written permission must be obtained from the copyright owner,

S. Karger AG, P.O. Box

CH-4009 Basel (Switzerland).

\section{Subscription Orders:}

Orders can be placed at agencies, bookstores, directly with the Publisher

\section{S. Karger AG}

Medical and Scientific Publishers

Allschwilerstrasse 10

CH-4009 Basel

Switzerland

$\mathrm{t}:+41613061111$

f: +41613061234

e: karger@karger.com

w: www.karger.com

(for courier services only:

Allschwilerstrasse 10

CH-4055 Basel) or further Karger offices

or representatives:

Germany

S. Karger GmbH

Postfach

79095 Freiburg

Deutschland

(Hausadresse: Wilhelmstrasse 20A

79098 Freiburg)

t: +49761452070

f: $\quad+497614520714$

e: information@karger.de

w: www.karger.de

Japan

Karger Japan, Inc

Shiba Daimon Asahi Bldg. 2F

1-2-23 Shiba Daimon

Minato-ku

Tokyo 105-0012

Japan

t: +81364356242

f: +81364356244

e: publisher@karger.jp

w: www.karger.jp
USA

S. Karger Publishers, Inc

26 West Avon Road

P.O. Box 529

Unionville, CT 06085

USA

Toll free: +18008285479

t: +18606757834

f: +18606757302

e: karger@snet.net

France

Librairie Médi-Sciences Sarl

36, bd de Latour-Maubourg

75007 Paris

France

t: $+33(0) 145514258$

f: $+33(0) 145560780$

e: librairie@medi-sciences.fr

w: www.medi-sciences.fr
South East Asia, China and Taiwan Karger Regional Office (Malaysia)

CEO Suite Kuala Lumpur

Quill 7, 27th Floor

Jalan Stesen Sentral 5

KL Sentral

Kuala Lumpur 50470

Malaysia

t: +60327766803

f: +60327766999

e: service@karger.cn; r.chew@karger.cn

\section{Karger China}

10th Floor, Twin Towers (East)

B12 Jianguomenwai Avenue

Beijing 100022

China

t: +861051235033

f: +861051235122

e: service@karger.cn; r.chew@karger.cn

w: www.karger.cn

India, Bangladesh, Sri Lanka

Medscience India

Plot No. 17, Yusuf Sarai Market

B.L. Glass Building, 2nd Floor

Sri Aurobindo Marg

New Delhi 110016

India

t: +911146029633

f: +911146029634

c: +919891052128

e: medsci.india@gmail.com

Change of Address:

Both old and new address should be sent

to the subscription source.

\section{KARGER}

E-Mail karger@karger.com www.karger.com
(C) 2013 S. Karger AG, Basel

The Journal Home Page is available at:

www.karger.com/ene 
30TH INTERNATIONAL CONGRESS

ON CLINICAL NEUROPHYSIOLOGY

Intenationsl Fedecation of Clinical Neunophnialogy

OF THE IFCN (ICCN)

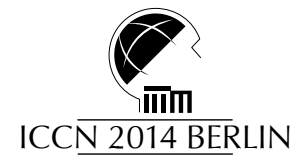

58 $8^{\text {TH }}$ ANNUAL MEETING OF THE GERMAN SOCIETY

FOR CLINICAL NEUROPHYSIOLOGY AND

FUNCTIONAL IMAGING (DGKN)

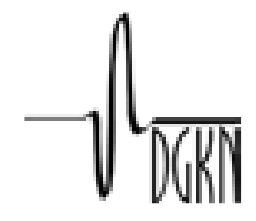

\section{MARCH 19-23, 2014 • BERLIN (DE)}

\section{Main Topics}

Consciousness and higher brain function

Development and aging

Nerve and muscle

Important Deadlines

Abstract Submission

Early Registration

30 September 2013

31 October 2013

\section{Satellite Events}

Course on Single-Fiber Electromyography (SFEMG) March 18-19, 2014

$6^{\text {th }}$ International Meeting of the Brain Stem Society (BSS)

March 18-19, 2014 


\section{Contents}

See the journal website for contents

KARGER Basel $\bullet$ Freiburg $\cdot$ Paris $\bullet$ London $\bullet$ New York $\cdot$ New Delhi $•$ Bangkok Beijing $\cdot$ Tokyo $\cdot$ Kuala Lumpur $\cdot$ Singapore $\bullet$ Sydney 


\section{European \\ Neurology}

(Continued from back cover)

95 Efficacy of Local Lidocaine Application on Anxiety and Depression and Its Curative Effect on Patients with Chronic Tension-Type Headache

Karadaş, Ö. (Erzincan); Inan, L.E.; Ulaş, Ü.H.; Odabaşi, Z. (Ankara)

113 Anti-Aquaporin-4 Antibody Positivity in Neuromyelitis Optica Is Associated with Lesion Activity

Liu, Y.; Han, Y.; Duan, Y.; Huang, J.; Ren, Z. (Beijing);

Butzkueven, H. (Parkville, Vic.); Li, K. (Beijing)

117 Central Adiposity and Mortality after First-Ever Acute Ischemic Stroke

Chiquete, E. (Mexico City); Ruiz-Sandoval, J.L.;

Murillo-Bonilla, L. (Guadalajara); León-Jiménez, C. (Zapopan); Ruiz-Madrigal, B.; Martínez-López, E.; Román, S.; Panduro, A.

(Guadalajara); Ramos, A.; Cantú-Brito, C. (Mexico City)

124 Intra-Arterial Chemotherapy Is Not Superior to Intravenous Chemotherapy for Malignant Gliomas: A Systematic Review and Meta-Analysis Chen, W. (Nanning/Hebei); Wu, Q.; Mo, L. (Nanning)

Historical Notes

48 On the Historical Succession of Vessel-Based Therapies in the Treatment of Multiple Sclerosis

Ganesh, A.; Stahnisch, F.W. (Calgary, Alta.)

106 The Neurology of Aretaeus: Radix Pedis Neurologia Pearce, J.M.S. (Hull)
Letter to the Editor

102 Spontaneous Hydromyelic Cavity in Two Unrelated Patients with Late-Onset Pompe Disease: Is This a Fortuitous Association?

Remiche, G. (Brussels); Ronchi, D.; Lamperti, C.; Bordoni, A.; Magri, F.; Moggio, M.; Comi, G.P. (Milan)

Neurologic Image

33 Bilateral Thalamic Lesions in a Child Jain, P.; Mohamed, A. (New Delhi); Sigamani, E. (Vellore); Suri, V.; Mahapatra, A.K.; Kumar, A.; Gulati, S. (New Delhi)

What Is Your Diagnosis?

46 Suction Lesion of Finger in a Woman Affected by Alzheimer's Disease

Vetrano, D.L.; Martone, A.M.; Onder, G.; Bernabei, R.; Landi, F. (Rome) 
Review

78 Is Vertebral Artery Hypoplasia a Predisposing Factor for Posterior Circulation Cerebral Ischemic Events? A Comprehensive Review

Katsanos, A.H.; Kosmidou, M.; Kyritsis, A.P.; Giannopoulos, S. (Ioannina)

\section{Original Papers}

1 Increased Carotid Intima-Media Thickness and Plasma Homocysteine Levels Predict Cardiovascular and All-Cause Death: A Population-Based Cohort Study Jung, J.-M.; Kwon, D.Y. (Ansan); Han, C. (Ansan/Seoul); Jo, I. (Seoul); Jo, S.A. (Cheonan); Park, M.H. (Ansan/Seoul)

6 'Distorteidolias' - Fantastic Perceptive Distortion A New, Pure Dorsomedial Thalamic Syndrome Delgado, M.G. (Oviedo); Bogousslavsky, J. (Glion)

10 A Prospective Study on 132 Cases of Ocular Palsy Castelluccia, A. (Rome); Nociti, V. (Milano); Frisullo, G.; Batocchi, A.P. (Rome)

16 Basilar Artery Atherosclerosis and Hypertensive Small Vessel Disease in Isolated Pontine Infarctions: A Study Based on High-Resolution MRI

Feng, C.; Xu, Y.; Bai, X.; Hua, T.; Li, Q.; Tang, G.-Y.; Chen, Y.-J.; Liu, X.-Y.; Huang, J. (Shanghai)

22 Sleep-Disordered Breathing and Periodic Limb Movements in Narcolepsy with Cataplexy: A Systematic Analysis of $\mathbf{3 5}$ Consecutive Patients Pizza, F. (Zürich/Bologna); Tartarotti, S.; Poryazova, R.; Baumann, C.R. (Zürich); Bassetti, C.L. (Zürich/Bern)

27 Sensory Conduction Study in Fisher Syndrome: Patterns of Abnormalities and Their Clinical Correlation Lyu, R.-K.; Chang, K.-H.; Chu, C.-C.; Kuo, H.-C.; Ro, L.-S. (Taoyuan)
35 Swiss Analysis of Multiple Sclerosis: A Multicenter, Non-Interventional, Retrospective Cohort Study of Disease-Modifying Therapies

Gobbi, C.; Zecca, C. (Lugano); Linnebank, M. (Zurich); Müller, S. (St. Gallen); You, X. (Weston, Mass.); Meier, R.; Borter, E.; Traber, M. (Zug)

42 Impact of Cognitive Dysfunction on Drooling in Parkinson's Disease

Rana, A.Q.; Khondker, S.; Kabir, A.; Owalia, A.; Khondker, S.; Emre, M. (Scarborough, Ont.)

59 Fatigue in Drug-Naïve Parkinson's Disease

Kang, S.Y. (Seoul/Hwaseong Si); Ma, H.-I.; Lim, Y.-M.; Hwang, S.H. (Seoul); Kim, Y.J. (Seoul/Anyang)

65 Optimization of Intravenous Immunoglobulin in Chronic Inflammatory Demyelinating Polyneuropathy Evaluated by Grip Strength Measurement

Kokubun, N.; Sada, T. (Tochigi); Yuki, N. (Singapore); Okabe, M.; Hirata, K. (Tochigi)

70 Neuromelanin Magnetic Resonance Imaging in Parkinson's Disease and Multiple System Atrophy

Matsuura, K.; Maeda, M.; Yata, K.; Ichiba, Y.; Yamaguchi, T.; Kanamaru, K.; Tomimoto, H. (Mie)

84 Safe and Effective Outcome of Intravenous Thrombolysis for Acute Ischemic Stroke in Patients Aged 90 Years or Older

Balestrino, M. (Genoa); Carlino, V. (Genoa/La Spezia); Bruno, C.; Finocchi, C.; Mancardi, G.L. (Genoa); Del Sette, M. (Genoa/La Spezia); Gandolfo, C. (Genoa)

88 Effects of Levetiracetam Monotherapy on the Cognitive Function of Epilepsy Patients

Koo, D.L.; Hwang, K.J.; Kim, D.; Kim, Y.-J.; Kim, J.Y.; Shin, W. (Seoul); Kim, M.R. (Seongman); Joo, E.Y.; Lee, J.-M.; Hong, S.B. (Seoul) 